\title{
Creating a New Program in Entrepreneurship Education: A Case Study in Colombia
}

Kirk C. Heriot

Noel D. Campbell

$E$ ntrepreneurship has been widely recognized as having greatly influenced the United States. Its influence has especially been documented over the past 20 years. Paralleling our societal interest in entrepreneurship has been increasing interest in entrepreneurship education. While our interest in entrepreneurship education has grown considerably over the past two decades, this field of study continues to have critics both within and outside of schools and colleges of business (Kuratko 2004). In spite of these criticisms, some researchers suggest that the United States is still far ahead of other regions of the world in terms of entrepreneurial education (Solomon et al. 1998).

Using entrepreneurship education in the United States as a point of departure, this article uses a case study to analyze the efforts of a private university in Bogota, Colombia, to create a new program in entrepreneurship. The Colombian Legislature passed Law 590 in July 2000 as a means to promote and develop entrepreneurship in the nation. Shortly thereafter a private university in Bogota started a new program in entrepreneurship. At the university's invitation, a small number of faculty from U.S. universities participated in the school's "kick-off" efforts. The paper offers analysis and recommendations based on five criteria: 1) What is taught, 2) Why it is taught, 3) How it is taught, 4) How well it works, and 5) Leadership support. In addition, rather than simply adopting a U.S. or European model of entrepreneurship education, the authors propose that they should develop a center that integrates lessons from other models with elements that are relevant to the local situation.

Colombia is a South American country widely perceived to have a variety of political and economic problems. The country suffers from a reputation as one of the most dangerous places in the world with more than 20,000 kidnappings each year (U.S. Department of State Website 2004). Much of its endemic violence is tied to the drug cartels that control many parts of the country.

In addition to political unrest, the Colombian economy has suffered a series of setbacks that have dissuaded outside investors (U.S. Department of State Website 2004). Perhaps in response to their economic problems, the Colombian legislature passed Law 590 in July 2000 to promote and develop entrepreneurship in the hope that Colombia could reap the benefits of entrepreneurship that other developed and developing nations seem to enjoy.
One author visited a private university in Bogota in November 2001 to present a seminar about export opportunities for Colombian small businesses. The university is a small, private, tertiary educational institution located in Bogota. The university was founded in the 1980s and offers degrees in law, industrial engineering, marketing, business administration, economics, finance and international trade, and philosophy. While visiting the university, a finance faculty representative informed the visiting author that the university would like assistance in starting a program in entrepreneurship. The process concluded in May 2004 when the same author returned to Bogota to offer additional advise on the proposed academic programs in entrepreneurship.

The purpose of this study is to describe our efforts to help the university create a program in entrepreneurship. As research on entrepreneurship education in developing nations is still in the exploratory stage (Garcia 1999), our choice of a research design was influenced by the limited theoretical knowledge researchers have of entrepreneurial education (Fiet 2001a). In this situation, it is appropriate to use a qualitative research method to gather the necessary information (Eisenhardt 1989; Yin 1994). The current research necessitated that we follow the process of starting a new entrepreneurship and small business center in great detail. Thus, we adopted a research method described by Audet and d'Amboise (1998) that was broad-minded and flexible. Like their study, our aim was "to combine rigor, flexibility and structure without unduly restricting our research endeavor" (Audet and 'Amboise 1998, p. 11).

We use a case study (Yin 1994) to describe the university's efforts to create a program in entrepreneurship. The literature suggests that many models of entrepreneurial education are followed (Fiet 2001a, Solomon, et al., 1998, and Shepherd and Douglas 1997), using a variety of pedagogies (Solomon, Winslow, and Tarabishy 1998), in many American and European colleges and universities. We had to choose a means for evaluating and advising the proposed program, given the director's desire to start a program that (1) teaches entrepreneurship; (2) conducts entrepreneurial research; and (3) provides consulting services. We decided to conduct the research project using a three-step approach. First, we began by surveying the extant literature to sample the models for creating and operating an entrepreneurship education program. Second, we evaluated the current state of the university's fledgling program.Third, we offered suggestions on what 
the university should do to start its entrepreneurship program. This article suggests ways that the university can best implement the proposed center by integrating its efforts across all of its business disciplines. Lastly, we used this information to draw conclusions about the efficacy of importing a U.S. model of entrepreneurship education into Colombia as well as how other tertiary educational institutions in Latin America can pursue the creation of new entrepreneurship centers.

\section{Supporting Literature}

The literature on entrepreneurship education in developing nations is still in a developmental stage (Garcia 1999). A review of the extant literature on entrepreneurship education shows that the field has been evaluated from a variety of perspectives including what is taught, why it is taught, how it is taught, and how well it works (see Gorman and Hanlon 1997; Vesper and Gartner 1997; Solomon, Winslow, and Tarabishy 1998). The problem with assessing entrepreneurship education is that no generally accepted pedagogical model has been adopted in the U.S. or Europe (Solomon, Winslow, and Tarabishy 1998). Given that some researchers suggest that " $[t]$ he concept of entrepreneurship is inadequately defined [, and] this lack of a clear entrepreneurship paradigm poses problems for both policy-makers and for academics" (Carton, Hofer, and Meeks 1998, p.1), the state of entrepreneurial education cannot be too surprising. If we cannot agree on the phenomena we are discussing, it becomes very difficult to develop a curriculum or build an academic program based upon those phenomena.

Solomon, et al. (2002) discuss the results of a 20-year investigation of teaching entrepreneurial education and small business management in the United States. Their data are based on six national surveys. They believe a trend exists toward greater integration of practical applications and technology. They note that new venture creation, small business management, and small business consulting remain the most popular courses in the field.

Shepherd and Douglas (1997) argue that entrepreneurial education falls into four categories: the old war stories approach, the case study approach, the planning approach, and the generic action approach. The old war stories approach provides a series of success stories told by entrepreneurs. The emphasis is on experience, intuition, and judgment. The leader's innate qualities are emphasized without any recognition of the contribution of the organization or the environment. This approach uses very little theory and emphasizes anecdotal evidence. The case study approach assumes that entrepreneurship is "a process that is a controlled and conscious thought process" (Shepherd and Douglas 1997). Mintzberg (1990) argues that this perspective assumes that formulation can be separated from acting, as if the world stands still while the planning occurs. The planning approach breaks a controlled, conscious process into a series of steps that lead to a full-blown strategy, often in the form of a business plan. Meyer (2001) argues that the use of business plans may be problematic. He questions whether we have validated the hypothesized positive relationship between business plans and firm performance. Shepherd and Doyle (1997) also question their usefulness because the very nature of planning is designed to extrapolate known trends. Thus, the planning process is too inflexible to accommodate the entrepreneurial spirit. The generic action approach is linked to the competitive markets model. It assumes that market forces, such as bluffing, price deterrence, and the timing of entry, dictate action. "Once formulated, there is no need for initiative, 'only' implementation" (Shepherd and Douglas 1997). This approach argues that after scanning the environment, the entrepreneur will be able to draw appropriate conclusions necessary to move in the right direction. Shepherd et al. are critical of this approach, arguing that this form of entrepreneurship education emphasizes the science of entrepreneurship while ignoring the art of entrepreneurship. Shepherd et. al. emphasize the importance of creative thinking and learning throughout entrepreneurship education. They believe entrepreneurship should be taught so that the direction is deliberate but the details are emergent.

Vesper and Gartner (1997) present the survey results of ranked university entrepreneurship programs. The top seven criteria for ranking these programs were courses offered, faculty publications, impact on community, alumni exploits, innovations, alumni start-ups, and outreach to scholars. American universities may wish to focus on these criteria as it develops a new entrepreneurship program. It remains to be seen if these criteria are meaningful or affordable for universities in other countries, particularly developing nations.

Garcia (1999) argues that Puerto Rico's economic development should be centered on small and medium enterprises (SME). She believes that such a model of economic development must focus on the educational system, arguing that "it is critical to take into consideration the region's history and informal context when designing entrepreneurship education models" (Garcia 1999, p. 1 of 7). Nonetheless, at the time of its publication, the article had not gathered information on measurable outcomes. The entrepreneurship program she described was only at a pilot stage, thus it remains to be seen whether her advice will be supported by the program's performance. Nonetheless, it represents the only commentary on the efficacy of a U.S. entrepreneurial education model in a Spanish-speaking area.1

Schaper's (2000) comments are also particularly useful as they directly consider the implications of transferring an entrepreneurial education system from one nation to another, arguing one must consider whether entrepreneurship 
concepts and skills can be transferred across borders. Transferring entrepreneurship to another region of the globe presents a variety of challenges. Schaper states that cultural issues impact entrepreneurial education because perspectives on risk-taking, individual initiative and personal achievement are different in different cultures. He concludes that a variety of techniques and methods should be used to teach entrepreneurship. Schaper's concerns are echoed in Albert and Watkins (1999): "We could go on, but let's just mention the challenge of multidisciplinarity, the desirability of multiestablishment co-operation, the need to continually develop new materials, the necessity to tailoring materials to local cultures and economic systems" (Albert and Watkins, 1999, 33).

\section{The University in Colombia}

The director of the proposed program indicated two objectives for the program. First, he wrote, "Our university (Universidad Sergio Arboleda) has the objective [sic] to be a leader working with SME and want [sic] to reinforce its relation with that sector considering its importance for the Colombian economic [sic]."

The second objective was to determine "how the university could collaborate to the development [sic] of the Colombian [SMEs] through research and consultant or assistance to improve management and how the university could promote an entrepreneurship culture to create new small business [sic]." The director wanted the new program to instill an entrepreneurial spirit in the students and to inspire graduates to start new commercial ventures and entrepreneurial firms. However, the program organizers were unsure of the metrics that would be appropriate for this goal. They had not had any significant "success" stories to describe over their brief history. Implied in all of this information was a desire to begin offering courses in entrepreneurship that were not being offered when the first author visited the university.

The primary investigator visited Bogota in November 2001. This initial visit permitted firsthand observation of the city, the university, the faculty, small business owners and students. The university is a private university located in Bogota. Founded in the 1980s, the university has a very small physical infrastructure, occupying only a portion of one city block. Nonetheless, the facilities were not below the U.S. observers' expectations and there were at least two ongoing construction projects, including the building that houses the College of Finance and International Trade. ${ }^{2}$ Classrooms were fairly modern and computers were available to students. One of the few differences visible to U.S. observers was the lack of private offices for faculty and staff, as the College of Finance and International Trade faculty shared a single room with work areas divided by partitions.

The university enrolls approximately 3,800 students in a variety of professional and liberal arts programs. The point of contact for this study was a senior faculty member in the College of Finance and International Trade, one of four colleges at the university that emphasize a business function. The other programs are marketing, economics, and business administration. Each college is similar to a department-size unit in a typical U.S. school or college of business, and operate quite independently of the other colleges. Students in one college take few courses in the other colleges. This model clearly differs from a typical U.S. business administration plan of study whereby students are expected to take a variety of common professional courses (i.e., finance, management, marketing, and economics) regardless of their major (accounting, marketing, operations management).

The typical plan of study in the university's business program requires 10 semesters of study. The first 7 semesters focus on detailed studies within a respective discipline. Students are expected to work as an intern during their eighth semester. Unlike U.S. universities, students do not generally take a balanced load of general education courses as well as courses within their business major. In addition, students do not take a strategic management course or any other common capstone course in general management.

As of November 2001, the university did not offer any courses in small business management, entrepreneurship, or new venture creation. Furthermore, the university did not have any faculty with formal training in entrepreneurship or experience starting and managing a new business or an entrepreneurial firm other than the university president, who founded the university. Many faculty members did not have degrees beyond the master's level. However, the program director has more than 30 years of industrial experience including extensive experience in joint ventures with American firms. While this experience may not lend itself to entrepreneurial education per se, it should help the director to administer and lead the center once it has been developed.

The university appeared to have strong relationships in the business community. During the second day of the first visit in 2001, more than 50 business executives from small firms attended a conference that included presentations from government officials, professional consultants, and university faculty emphasizing ways that the Colombian small firms could export their goods and services. A similar program on the second visit in May 2004 had even more participation from business executives from small firms, government agencies, and public universities.

\section{Analysis and Recommendations}

Upon reading the literature on entrepreneurship education and observing the current situation at the university, one of the few definitive conclusions one can reach is that the university is starting its new program with very few visible, tan- 
gible resources. However, it may possess intangible resources that may benefit the center.The large turnout for the seminar represents an impressive network of small firms to draw from in the community. These firms could very easily be the source of guest speakers and benefactors for the program. The sheer size of Bogota, portends a great deal of potential for any business-oriented centers or programs.

In spite of its resource base, we believe the proposed center should focus on five criteria as part of its planning process. These criteria are consistent with the areas of interest described in the supporting literature. They are based on a synthesis of Vesper and Gartner (1997), Solomon, et. al. (2002), Katz, (2003), and Kuratko (2004). The five criteria are:

1. What is taught.

2. Why it is taught.

3. How it is taught.

4. How well it works (see also Gorman and Hanlon 1997).

5.To this list we add a fifth criterion-"leadership support."

\section{Leadersbip Support}

Leadership support is not specifically discussed in the entrepreneurship education literature. However, it is important to understand the contextual differences between programs in entrepreneurship in American universities versus universities in developing nations. The entrepreneurship programs highlighted in the extant literature have robust support systems. Additionally, the U.S. and European universities that started new entrepreneurship programs are, themselves, supported by stronger national economies and more government stability than Colombia. While the phenomena of entrepreneurship may not be as articulated and accepted in Europe as in the United States these countries are more stable and economically sound than Colombia. Lacking tangible financial support and an aggressively established entrepreneurial education movement, it is imperative that the university's president supports the creation and administration of the proposed center. Twaalfhoven (1999) argues that financial support and human resource support are critical. The university will need to hire additional faculty. In addition, the center will need to determine the budget necessary to operate. Twaalfhoven's comments regarding external funding by alumni and entrepreneurs are particularly germane. Many entrepreneurship programs in the United States were created or expanded following very substantial contributions from generous individuals. While the university may not have access to these sources of funding presently, it may turn to the government funding available through Law 590. Until such support materializes, university leadership must make the commitment to keep the new center afloat.

As of May 2004, the original acting director of the entrepreneurship center had been advanced to a new position in the finance and international business program. Thus, the university was seeking to find someone to permanently become the new director of the entrepreneurship program. Two adjunct faculty were teaching an entrepreneurship course when the second visit was conducted in May 2004.

Jose $S$. is an entrepreneur and former administrator in the Colombian Foreign Trade Ministry. ${ }^{4}$ He completed his undergraduate degree in engineering at Purdue University and his MBA at a public university in Colombia. He has also completed an entrepreneurship certificate program conducted by a nonprofit organization in India.

Maria $\mathrm{O}$. is a former honors student at the university with an undergraduate degree in finance and international trade. She is a very confident young woman that has shown a great deal of interest in teaching. However, she does not have any formal training or experience in entrepreneurship, nor does she have a graduate degree.

In June 2004, Jose informed the lead author that he had left the university. ${ }^{5}$ He left the university to begin working with a competing private university in Colombia. Ironically, Jose provided the lead author with a timetable for creating the Center for Entrepreneurship (shown as Table 1).Thus, he was exercising informal leadership in spite of his role as an adjunct faculty member.

Thus, leadership of the program remains unresolved and may become a major impediment to continued success, unless the former director oversees the program or a new individual is selected to become the director. ${ }^{6}$

\section{What Is Taught}

The program should follow what Plaschka and Welsch (1990) call a trial and error basis. We strongly suggest that the program start with an introductory course in entrepreneurship. Initially, instructors may need to use an existing textbook that is tailored to their needs. Unfortunately, after discussions with textbook publishing representatives, we conclude that American publishers have translated very few entrepreneurship textbooks into Spanish. ${ }^{7}$

As successive courses are developed, the center should use feedback from students, faculty, and practicing entrepreneurs to identify gaps, deficiencies, and difficulties in specific courses. The plethora of courses that are offered in universities in the United States and Europe suggests that a large variety of topics will elicit interest. It would appear that new venture creation and small business management are among the most popular courses with students, and perhaps small business counseling as well. It is probably premature to offer a consulting course without considerable preparation by the faculty. Student-based counseling is very popular in the United States For example, the Small Business Institute program is twenty-six years old (SBI Website 2004). 
Table 1. Schedule for the Implementation of the Entrepreneurship Program

\begin{tabular}{|c|c|c|c|c|c|c|}
\hline Activities & $\begin{array}{l}\text { April } \\
12 / 04\end{array}$ & $\begin{array}{l}\text { April } \\
30 / 04\end{array}$ & $\begin{array}{l}\text { May } \\
31 / 04\end{array}$ & $\begin{array}{l}\text { June } \\
30 / 04\end{array}$ & July/04 & $\begin{array}{c}\text { January } \\
2005\end{array}$ \\
\hline $\begin{array}{l}\text { 1. Identification and selection of physical place } \\
\text { to locate the program. Initiation of activities }\end{array}$ & XXXXX & & & & & \\
\hline $\begin{array}{l}\text { 2. Database compilation of information material } \\
\text { to be used in the program. }\end{array}$ & XXXXX & XXXXX & & & & \\
\hline $\begin{array}{l}\text { 3. Database compilation of potential students to } \\
\text { be involved in the entrepreneurship program }\end{array}$ & XXXXX & XXXXX & XXXXX & & & \\
\hline $\begin{array}{l}\text { 4. Design of final structure of International } \\
\text { Business Trips (VEC), and projections for the } \\
\text { period 2004-2008. }\end{array}$ & XXXXX & XXXXX & XXXXX & XXXXX & & \\
\hline $\begin{array}{l}\text { 5. Database compilation of advisors to be } \\
\text { trained in Entrepreneurship Development } \\
\text { (University Teachers and Consultants) }\end{array}$ & XXXXX & XXXXX & XXXXX & & & \\
\hline $\begin{array}{l}\text { 6. Design of functions manual for the program, defin- } \\
\text { ing registration and graduation option require- } \\
\text { ments trough business plans or export plans. }\end{array}$ & XXXXX & XXXXX & XXXXX & XXXXX & & \\
\hline $\begin{array}{l}\text { 7. Design of the research line on entrepreneur- } \\
\text { ship as a graduation option, such as business } \\
\text { plans or export plans. }\end{array}$ & XXXXX & XXXXX & XXXXX & & & \\
\hline $\begin{array}{l}\text { 8. Incorporate the activities of the Exporters } \\
\text { Center (ZEIKY) with the Entrepreneurship } \\
\text { Program. }\end{array}$ & XXXXX & XXXXX & XXXXX & & & \\
\hline $\begin{array}{l}\text { 9. Review and measure curriculum structure and } \\
\text { other activities that match the program's activities. }\end{array}$ & XXXXX & XXXXX & XXXXX & XXXXX & & \\
\hline $\begin{array}{l}\text { 10. Promote the program's activities and services } \\
\text { to the School of Business. }\end{array}$ & & & & & $\overline{X X X X X}$ & \\
\hline $\begin{array}{l}\text { 11. Implementation of defined actions for the } \\
\text { International Business Trips (VEC) }\end{array}$ & & & & & XXXXX & \\
\hline $\begin{array}{l}\text { 12. Implementation of courses for advisors to be } \\
\text { trained in Entrepreneurship Development } \\
\text { (University Teachers and Consultants) and } \\
\text { outsiders. }\end{array}$ & & & & & XXXXX & \\
\hline $\begin{array}{l}\text { 13. Implementation and follow up of early identi- } \\
\text { fied business ideas of registered students. }\end{array}$ & & & & & XXXXX & \\
\hline $\begin{array}{l}\text { 14. Promote findings in the research about entre- } \\
\text { preneurship. }\end{array}$ & & & & & XXXXX & \\
\hline $\begin{array}{l}\text { 15. Development of contacts with outsiders at } \\
\text { national or international meetings. }\end{array}$ & & & & & XXXXX & \\
\hline $\begin{array}{l}\text { 16. Implementation of the graduation option relat } \\
\text { ed to the program's activities. }\end{array}$ & & & & & XXXXX & \\
\hline $\begin{array}{l}\text { 17. Promote the program's activities and servic- } \\
\text { es to the entire university community. }\end{array}$ & & & & & & XXXXX \\
\hline
\end{tabular}


A critical review of well-known programs at other universities $^{8}$ suggests that it would be helpful to consider the following courses to support the academic program in Entrepreneurship:

- Entrepreneurial Marketing

- Entrepreneurial Finance

- Legal and Regulatory Environment

- New Venture Creation II or Entrepreneurship II, a follow-up to the introductory course in Entrepreneurship

\section{Why It Is Taught}

Our prior recommendation that introduction to entrepreneurship be the first course offered through the center is a fundamental decision. Entrepreneurship and small business management are very popular courses. However, it will be particularly important for students in a developing nation with the challenges that Colombia faces to learn why entrepreneurship is so promising.

Colombia faces many challenges, not the least of which is the crime and violence that dominate daily life. In addition, the country has not entirely embraced the economic, social, and legal freedoms that are so critical to entrepreneurship. The country still has remnants of its colonial past and its citizens are not guaranteed basic economic freedoms such as property rights that are largely taken for granted in most industrial nations. Thus, it may be important to compare and contrast entrepreneurship in Colombia with entrepreneurship in developed nations so that the students can begin to appreciate the many benefits that are possible from entrepreneurship.

The recommendation that marketing and finance courses be offered is consistent with the importance of these functions to any business endeavor (Association to Advance Collegiate Schools of Business 2004).A course in legal and regulatory issues is critical to the understanding of how Colombians can be entrepreneurial within the constraints imposed by their legal system. This course should emphasize the local conditions of law, contract enforcement, property rights transference and enforcement, access to capitalization, and property rights stability. We envision that this course should also compare and contrast the legal and regulatory environment in Colombia with the environment faced by entrepreneurs in other nations (Reynolds, Hay, and Camp 1999).

The use of a second course in entrepreneurship is consistent with our review of other programs as well as our discussions with more than 20 entrepreneurship educators at the Experiential Classroom, a program, now in its fifth year at Syracuse University, that discusses tools and techniques for teaching entrepreneurship. These educators believe that the first course can be used to teach students fundamental concepts in entrepreneurship, while the second course can be used to help the students apply the knowledge they have accumulated in the program by writing a business plan or completing some other major project.

\section{How It Is Taught}

Pedagogical issues are among the most debated in the entrepreneurship education literature (Fiet 2001b). A variety of techniques are used in entrepreneurship and small business management courses. These techniques include, but are not limited to, case studies, lectures, experiential exercises, business plans, consulting projects, and guest speakers. Just as entrepreneurship itself is often associated with creativity and innovation (see, e.g., Kuratko and Hodgetts 2001), teaching entrepreneurship has similar associations. The faculty should feel free to use any technique they believe will enhance the learning environment. As Schaper (2000) argues, numerous techniques are a wiser choice than only one or two regular techniques.

Nonetheless, while we expect lectures to be the primary pedagogy, we urge the university to consider other techniques that will force students to participate in the learning process. Given the nature of entrepreneurship and the desire of the university to instill the entrepreneurial spirit in its students, its seems entirely appropriate for its faculty to adopt teaching techniques that compel students to actively engage in learning as opposed to simply passively taking notes as an instructor conducts a lecture.

\section{How Well It Works}

The program can be evaluated using a variety of benchmarks. Vesper and Gartner's research (1997) indicate that highly ranked programs are evaluated based on course offerings, faculty publications, community impact, alumni exploits, innovations, alumni start-ups, and outreach to scholars. These categories reflect a set of U.S. standards that are the cumulative result of more than 20 years of teaching entrepreneurship. Garcia (1999) warns that using American standards and values to create a program in entrepreneurship outside the United States will not succeed. She argues that a program to teach entrepreneurship must reflect formal (economic and political systems) and informal factors (norms and culture).

We believe the university should select three or four standards that may or may not reflect the American experience. Then, the university should monitor achievements in those areas and compare the outcomes to its expectations. If it seeks input from entrepreneurs, then the input should be part of their assessment efforts (Solomon, Winslow, and Tarabishy 1998).

We believe the following standards represent an initial set of metrics that can be modified as the program grows or changes direction: 
1. Size of program based on student enrollments. Is the program growing? Do increasing numbers of students begin to express an interest in entrepreneurship?

2. Number of courses that are offered with greater than average enrollment (equal to or greater than the university average). What courses seem to be receiving the most attention? Low enrollment may reflect lack of interest in a topic or it may simply reflect poor teaching on the part of an instructor.

3. Number of academic papers that are presented by faculty over a five-year period. Academic reputation may not be quite as important in Colombia as it appears to be in the United States. Nonetheless, it remains a metric that is easily understood and demonstrates the commitment of faculty to pursue professional development in the field of entrepreneurship.

4. Number of new business ventures started or managed by participants in the entrepreneurship program. This outcome may take several years to occur, but it is not unreasonable to expect some of the students in the program to use their newfound skills to start new business ventures.

\section{Limitations}

This study is limited by the nature of case studies (Yin 1994). The findings of case studies cannot always be generalized to other situations. However, given the lack of a universal model for entrepreneurship education, especially in a developing nation, it was both practically and theoretically appropriate to use a case study. While the results of this research may not specifically be extended to other Latin American universities, the faculty and administration at other universities may certainly use the current study as the basis for their own efforts to start an entrepreneurship and small business center.

\section{Discussion}

For the university in Bogota to successfully implement its program, it must find a means to selectively borrow from a variety of entrepreneurship education models in the United States and Europe. Our point of contact was with faculty in the College of Finance and International Trade. However, other business programs at the university should be involved in the proposed entrepreneurship and small business center. Shepherd and Douglas (1997) argue that one "must look beyond the limits of the functional disciplines." Presently, each of the business colleges at the university operates as somewhat autonomous units. Students do not necessarily become exposed to theories outside their relatively circumscribed major academic area. Yet, entrepreneurship is an eclectic discipline that borrows heavily from psychology, economics, marketing, and strategic management (Schindehutte et. al. 2000). We believe it would be a serious error if the entrepreneurship and small business center did not invite participation from faculties in marketing, economics, and business administration.

The university finds itself on the brink of an exciting adventure.Albert and Watkins (1999) note that entrepreneurship can be a challenging and time-consuming task. The field of entrepreneurship requires its advocates to think in ways that are very different than traditional business courses or business paradigms (Shepherd and Douglas 1997). While completely adopting a U.S. model for entrepreneurial education is not the best course of action (Garcia 1999), beginning with and modifying U.S. programs may be a wise place to start, given the apparent progress in American universities.

The university must be prepared to adjust its program to account for formal cultural resistance to entrepreneurship and entrepreneurship education. Many Latin countries still struggle with the social remnants of colonial administration. Powerful elements within society may resist entrepreneurial expansion of wealth and economic power, fearing it will further infringe upon their historical social and political control. Additionally, many Latin countries have large socialistic elements within society. Many factions of socialist ideology are determinedly antientrepreneurial. Due to this potential social resistance, universities may experience unusual difficulties in attracting private funds to their entrepreneurship center; a change in government may end governmental funding as more "conservative" or "progressive" (both potentially antientrepreneurial) elements come to power. Their entrepreneurship program may experience difficulty attracting quality students if entrepreneurship becomes a socially stigmatized or marginalized field of study. For similar reasons, universities should also consider that their graduates might face difficulties attracting customers, especially large corporate or government accounts, to their entrepreneurial firms.

\section{Summary}

We believe that the university has chosen to embark on a challenging and highly rewarding course of action. After reviewing the university's situation, we have recommended that it address criteria in five major areas in order to achieve their stated objectives. We believe the five criteria should be as follows:

1. What is taught. The university should start by offering a fundamental course in entrepreneurship that is followed by other courses such as entrepreneurial marketing, entrepreneurial finance, legal and regulatory environment and a "capstone" course.

2. Why it is taught. The university should also emphasize the benefits of entrepreneurship. Yet, it must do so in the proper context that recognizes the unique social and political differences between Colombia and the United States. 
3. How it is taught. The program will probably use a traditional lecture method, but we believe that contemporary pedagogies should be adopted as soon as faculty and students become familiar with them. These pedagogies, such as student consulting and the case method, have received considerable attention among entrepreneurship educators. (See, for example, the Experiential Classroom at Syracuse University, currently in its fifth year. This program demonstrates several tools and techniques for teaching entrepreneurship.)

4. How well it works. We have suggested four possible metrics with an emphasis on student enrollment. Student demand for courses in entrepreneurship is a clear indicator of the viability of the concept, especially at a private university that does not have the benefit of public funding.

5. Leadership support. The university must select an individual to lead its entrepreneurship program. The transition of the original director to another position has left a void that had not been filled as of June 2004. The former director cannot continue to perform his current as well as his former duties.

\section{Conclusions}

The university must learn to recognize and embrace entrepreneurship in all of its forms and by all of its practitioners, and reject cultural formalism by focusing on the phenomenon, regardless of where it occurs or by whom. Entrepreneurship in Latin America may be robustly flourishing, but in the most unexpected place and carried out by the most unexpected people, as documented by De Soto (1989). Writing of Peru, De Soto finds that in Lima, Peru, alone, entrepreneurial "black marketers" "employ 439,000 people. Of the 331 markets in the city, 274 have been built by the black marketers....... [T]hanks to them the citizens are able to get around, because 95 percent of public transportation belongs to them.... Half the population of Lima lives in houses built by black marketers.... These numbers speak eloquently of the productive energy that restrictive legality has pushed into the black market." (De Soto 1989, pp. xiii-xiv) Of De Soto's work, Mario Vargas Llosa writes, "The concept of liberty, in all its sense, has never been seriously applied in our countries. Only now, in the most unexpected way, through the spontaneous actions of the poor, is it beginning to gain ground, showing itself to be a more sensible and effective solution than any undertaken by our conservatives and progressives as ways of overcoming underdevelopment" (De Soto $1989, \mathrm{p}$. xvii). If the university is willing to look for and embrace entrepreneurship in unlikely quarters, the university will find it.

The university must be prepared to recognize the need to adapt the "received wisdom" from U.S. and European sources (texts, instructors, speakers, and programs) to the local conditions of law, contract enforcement, property rights transference and enforcement, access to capitalization, and property rights stability. The United States and Europe have enjoyed stable political and legal systems and transferable and governmentally supported property rights for so long that frequently such issues no longer explicitly appear in academic analysis. Citizens, businesspersons, and academics take these conditions for granted. For example, consider teaching an American business case in which the business plan depends on rapid, easy, and legal acquisition of title to real estate, wherein title is conveyed based on a bank loan secured previously. Now consider teaching the same case in a society in which law and red tape prohibitively discourage legal transfers of real property, and in which banks lend only to certain social classes or castes, and almost never make mortgage loans. A business model, and its use in education, which works under the U.S. institutional framework may not work at all in other societies operating under other institutional frameworks.

\section{Endnotes}

1 While Puerto Rico is a territory of the U.S., in many respects, such as competition in the Olympics every four years, it takes great pride in its Hispanic heritage. Spanish remains the primary language of Puerto Ricans.

2 These two projects were completed and a new building was being constructed to house a School of Law and a Graduate Business Program as of May 2004.

3 The business literature is filled with numerous suggestions that argue that successful implementation of a new program or strategy requires leadership.

4 The names of these individuals have been disguised to respect their privacy.

5 The lead author exchanged e-mails with Jose for about a six-month period. Jose also served as his unofficial host during the May 2004 visit.

6 The individual who left the university provided a timetable for creating the program at the university. This timetable is shown as Table 1 . It has not been formally adopted by the university. 
7 The best-selling textbook, Small Business Management, by Longenecker, Moore, and Petty, is published in Spanish by Thomson/South-western. A copy was provided to the program director during the visit in November 2001 as a gift.

8 We looked at the programs at five universities that have been recognized by the United States Association for Small Business and Entrepreneurship (USASBE) for their undergraduate programs in entrepreneurship. Clearly, other programs are also quite exceptional, but these programs were selected due to their special recognition.

\section{References}

Association to Advance Collegiate Schools of Business Website. 2004. Retrieved June 14, 2004.

Albert, Philippe, and David Watkins. 1999. Entrepreneurship education is spreading through Europe, but far too slowly. Efmd Forum 1:30-34.

Audet, Jose, and Gerald d'Amoise. 1998. The relationship between strategic scanning activities of small and medium-sized enterprises and their performance:A multi-site study approach. Proceedings of the United States Association of Small Business and Entrepreneurship. Retrieved December 15, 2001. (http://www.sbaer.uca.edu/Research/ 1998/USASBE/98usa296.txt).

Carton, Robert B., Charles W. Hofer, and Michael D. Meeks. 1998. The entrepreneur and entrepreneurship: Operational definitions of their role in society. Proceedings of the 1998 International Council for Small Business World Conference. Retrieved December 15, 2001. (http://www.sbaer.uca.edu/Research/1998/ICSB/k004.htm).

De Soto, Hernando. 1989. The other path: The invisible revolution in the third world. New York: Harper \& Rowe.

Eisenhardt, Kathleen M. 1989. Building theories from case research. Academy of Management Review 14, 4: 532-550.

Fiet, James O. 2001a. The theoretical side of teaching entrepreneurship. Journal of Business Venturing 16: 1-24.

Fiet, James O. 2001b. The pedagogical side of entrepreneurship theory.Journal of Business Venturing 16: $101-117$.

Garcia, Marines Aponte. 1999. Entrepreneurship education:An institution for development of Puerto Rico's model. Proceedings of the 1999 International Council for Small Business World Conference. Retrieved December 15, 2001. (http://www.sbaer.uca.edu/Research/ 1999/ICSB/99ics253.htm).

Gorman, Gary, and Dennis Hanlon. 1997. Some research perspectives on entrepreneurship education, enterprise education, and education for small business management:A ten-year literature review. International Small Business Journal 15, 3: 56-77.

Katz, J.A. 2003. The chronology and intellectual trajectory of American entrepreneurship education.Journal of Business Venturing 18, 2: 283-300.

Kuratko, Donald G., and Richard M. Hodgetts. 2001. Entrepreneurship: A contemporary approach. Fort Worth: Harcourt Publishers, Inc.

Kuratko, Donald G. 2004. Coleman White Paper. Entrepreneursip education in the 21st century: From legitimization to leadership. Presented at the 2004 Annual Meeting of the U.S.Association for Small Business and Entrepreneurship.

Meyer, G. Dale. 2001. Major unresolved issues and opportunities in entrepreneurship education. Proceedings of the United States Association for Small Business and Entrepreneurship and Small Business Institute Director's Association Joint Meeting. February 8, 2001. Retrieved June 11, 2003. (http://www.sbaer.uca.edu/Research/2001/USABESBIDA/pdffiles/PAPERS/Volume1/001.pdf).

Mintzberg, H. 1990. Strategy formation:Ten schools of thought. In J. W. Fredrickson, ed., Perspectus on Strategic Management. New York: Harper and Row.

Plaschka, Gerhard R., and Harold P.Welsch. 1990. Emerging structures in entrepreneurship education: Curricular designs and strategies. Entrepreneurship:Theory \& Practice 14, 3: 55- 70.

Reynolds, P. D., M. Hay, and S. M. Camp. 1999. Global entrepreneurship monitor. Kauffman Center for Entrepreneurial Leadership.

Schaper, Michael. 2000 Delivering entrepreneurship education across borders, across cultures. Proceedings of the 2000 International Council for Small Business World Conference. (http://www.sbaer.uca.edu/research/icsb/2000/pdf/38.PDF)

Schindehutte, Minet, Michael H. Morris, and Donald F. Kuratko. 2000. Classification as a factor in the scientific evolution of entrepreneurship. Journal of Small Business Strategy 11, 2: 1-20.

Shepherd, Dean A., and Evan Douglas. 1997. Is management education developing, or killing, the entrepreneurial spirit? Proceedings of the 1997 International Council for Small Business World Conference. Retrieved December 15, 2001. (http://www.sbaer.uca.edu/ Research/1997/ICSB/97ics073.htm)

Small Business Administration Website. 2004 (www.sba.gov). 
Small Business Institute. 2004. Archival Database (www.smallbusinessinstitute.net).

Small Business World Conference. Retrieved December 15, 2001.

(http://www.sbaer.uca.edu/Research/2000/ICSB/pt1/038SCH.PDF).

Solomon, George T., Erik K. Winslow, and Ayman Tarabishy, 1998. Entrepreneurial education in the United States:An empirical review of the past twenty years. Proceedings of the 1998 International Council for Small Business World Conference. Retrieved December 15, 2001. (http://www.sbaer.uca.edu/ Research/1998/ICSB/i002.htm).

Solomon, George T., Duffy, S. and Tarabishy,A., 2002. The state of entrepreneurship education in the United States:A nationwide survey and analysis. International Journal of Entrepreneurship Education 1, 1:65 - 86.

Twaalfhoven, Bert W.M. 1999. Entrepreneurship education and its funding a comparison between Europe and the United States. Efmd Forum 3: 50-53.

U.S. Department of State Website. 2004. (www.state.gov).

Vesper, Karl, and William B. Gartner. 1997. Measuring progress in entrepreneurship education. Journal of Business Venturing 12, 5: 403-421.

Yin, R. K. 1994. Case study research: Design and methods, 2nd ed.Thousand Oaks, CA: Sage Publications

\section{About the Authors}

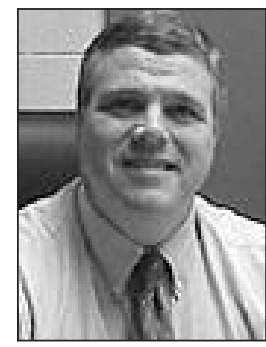

KIRK C. HERIOT (heriot_kc@mercer.edu) joined the faculty at Mercer University in July 2005 as an associate professor of management. He has previously taught at universities in Pennsylvania, South Carolina, and Kentucky. Dr. Heriot has conducted academic research that has been published in peer-reviewed journals such as the Journal of Management Education (forthcoming), New England Journal of Entrepreneurship, Palmetto Review, Academy of Entrepreneurship Journal, American Business Review, Journal of Supply Chain Management, Journal of Small Business Strategy, and Coastal Business Journal. His research focuses on entrepreneurship in challenging environments, entrepreneurship

education, and small business strategy. Prof. Heriot is an active member in the United States Association for Small Business and Entrepreneurship and an officer in the Small Business Institute.

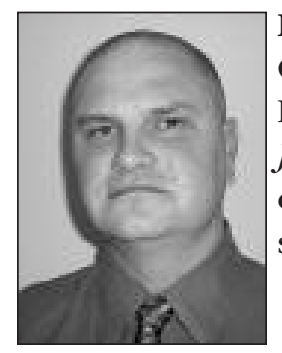

NOEL D. CAMPBELL (ndcampbell@ngcsu.edu) is an associate professor of business administration at North Georgia College \& State University. He completed his Ph.D. in economics at George Mason University in 1997. His research has been published in Public Finance Review, Journal of Real Estate Finance E Economics, Journal of Small Business Strategy, and Pennsylvania Journal of Business and Economics. Dr. Campbell's current work includes projects on family business succession, state educational lotteries, such as the HOPE scholarship, and business planning and firm performance. 